Niepełnosprawność. Dyskursy pedagogiki specjalnej

Nr 29/2018

Disability. Discourses of special education

No. $29 / 2018$

Sławomira Sadowska

Uniwersytet Gdański

Zdzisława Janiszewska-Nieścioruk

Uniwersytet Zielonogórski

\title{
O diagnozie z wykorzystaniem ICF jako podstawie organizowania pomocy osobom z niepełnosprawnością - między polityką, wiedzą naukową a praktyką
}

Podstawy teoretyczne i metodologia ICF rodzą duże nadzieje na wykorzystywanie jej w codziennej pracy i stawiają duże oczekiwania wobec praktyków - oczekiwania w zakresie rozumienia podstaw teoretycznych ICF i oczekiwania w zakresie wiedzy o modelu tej diagnozy oraz znaczeniu tego modelu dla organizacji procesu rehabilitacji (możliwościach i ograniczeniach). Analiza kluczowego problemu rozciąga się pomiędzy polem propozycji wykorzystywania ICF wysuwanych przez Ministerstwo Edukacji Narodowej, Ministerstwo Zdrowia, Ministerstwo Rodziny, Pracy i Polityki Społecznej, przestrzenią świadomości podmiotów odpowiedzialnych za organizowanie pomocy i przestrzenią innych modeli diagnozy. Dociekania pozwalają na stwierdzenie, że postulat wykorzystania ICF w praktyce rehabilitacyjnej, w tym w pracy z uczniami z niepełnosprawnością w szkole, napotyka na wiele ograniczeń. Ocena obiektywna problemów musi uwzględniać subiektywne odniesienie do nich osoby z niepełnosprawnością. Uwzględnienie tych perspektyw zapewnia interakcyjny model diagnozy, który powinien być urzeczywistniany w praktyce rehabilitacyjnej (diagnoza interakcyjna to rozwiniecie diagnozy funkcjonalnej). Praktyczne spełnienie tej propozycji może być wyraźnie osłabione odgórną wykładnią diagnozy w duchu funkcjonalnym. Osobista perspektywa widzenia niepełnosprawności osób zaangażowanych w pomoc oraz ich podejście do diagnozy wyraźnie odbiega od wykładni teoretycznej na jakiej opiera się model interakcyjny. Często też jest daleka od wykładni przyjmowanej w klasyfikacji ICF. W przestrzeni myślenia o niepełnosprawności osób zaangażowanych w pomoc, w tym nauczycieli, dominuje często tradycyjna wiedza naukowa. Praktyka w zakresie diagnozy ujawnia, że wiedza instytucjonalna i wiedza potoczna nierzadko ma większą moc regulacyjną od wiedzy naukowej.

Słowa kluczowe: niepełnosprawność, diagnoza, wiedza naukowa, praktyka pomocy.

\section{On application of ICF in diagnosis as a foundation for providing help to people with disabilities. Between policy, scientific knowledge and practice}

The theoretical framework and the ICF methodology often contribute practitioners' hopes and expectations to use ICF in everyday work. Particularly they affect expectations concerning the understanding of ICF's theoretical basis, as well as those concerning knowledge about the model of 
this type of diagnosis and its importance in organizing rehabilitation (regarding both possibilities and drawbacks). The presented analysis is focused on the potential uses of the ICF proposed by: the Ministry of Education, the Ministry of Health, and the Ministry of Family, Labor and Social Policy, as well as the knowledge and understanding of the entities, responsible for organizing help and other models of diagnosis. This inquiry has led to believe that the postulate of using ICF in rehabilitation, including everyday practice work with students with disabilities at schools, usually faces numerous obstacles. An objective assessment must include a subjective conviction expressed by a person with a disability. Conjunction of both perspectives allows the functioning of an interactive model of diagnosis, which should be implemented in the rehabilitation, however, bringing it into practice might be significantly impeded by the top-down approach of a diagnosis, regarded with a functional approach. A personal perspective of disability of people involved in helping and their approach towards diagnosis often differs significantly from the theoretical framework the interactive model is based on. Often it also differs from the interpretation adopted by the ICF classification itself. Traditional scientific knowledge usually dominates the way of thinking about disability of people involved in helping, including teachers. That frequently brings those standpoints to "naive" beliefs. The practice of diagnosing reveals that the institutional knowledge and "common knowledge" often dominates the scientific one.

Keywords: disability, diagnosis, scientific knowledge, helping

\section{Wprowadzenie}

W komunikacie z 24 lutego 2017 r. [Reforma edukacji a uczeń ze specjalnymi potrzebami edukacyjnymi, 24.02.2017] Ministerstwo Edukacji Narodowej, informując o reformie edukacji w kontekście uczniów ze specjalnymi potrzebami edukacyjnymi, zapowiada o trwających pracach nad przygotowaniem nowych rozwiązań mających na celu podniesienie jakości wsparcia udzielanego uczniom $\mathrm{w}$ procesie kształcenia i wychowania. Prace dotyczą zmian w diagnozie potrzeb. Jak informuje MEN w punkcie 5. „,elem zmiany jest przejście od modelu medycznego opartego na rozpoznaniu medycznym (np. przyporządkowaniu do określonej grupy/rodzaju niepełnosprawności na podstawie rozpoznania lekarskiego i/lub diagnozy psychologicznej i na tej podstawie wnioskowania o potrzebach) na rzecz modelu społecznego, opartego na analizie funkcjonowania dziecka i wynikających z tego potrzeb w zakresie zarówno wsparcia dziecka, jak i dostosowania środowiska zewnętrznego (dostosowanie warunków nauczania - likwidacja barier architektonicznych, dostosowane miejsce pracy, odpowiednie pomoce dydaktyczne, metody pracy dydaktycznej i wychowawczej itp.). Ten model diagnozy oparty jest na analizie nie tylko danych o indywidualnych cechach dziecka, ale również na barierach i zasobach $w$ jego środowisku, z uwzględnieniem informacji z różnych źródeł (np. lekarz, szkoła, opieka społeczna)"1 [Reforma edukacji a uczeń ze specjalnymi potrzebami edukacyjnymi, 24.02.2017]. MEN ogłasza

1 Zmiany podkreślane przez MEN w diagnozie potrzeb ucznia wskazują na przejście nie do modelu społecznego lecz bio-psycho-społecznego uwzględniającego stan zdrowia, zdolności i cechy oraz środowisko ucznia. Tym samym respektują rozwiązania proponowane w ICF. 
jednocześnie: „W nowym modelu planuje się wykorzystanie Międzynarodowej Klasyfikacji Funkcjonowania, Niepełnosprawności i Zdrowia - wersji dla dzieci i młodzieży (ICF-CY) ${ }^{2}$. MEN współpracuje w tym zakresie z Radą ds. ICF. Do współpracy zostali zaproszeni również przedstawiciele Ministerstwa Zdrowia i Ministerstwa Rodziny, Pracy i Polityki Społecznej" [Reforma edukacji a uczeń ze specjalnymi potrzebami edukacyjnymi, 24.02.2017, pkt 5.].

Czy przestrzeń propozycji wykorzystania ICF w praktyce napawa optymizmem? Na jaki grunt myślenia profesjonalistów o osobach z niepełnosprawnością i o procesie diagnostycznym nakłada się projekt nowych rozwiązań w zakresie diagnozy, mających na celu podniesienie jakości wsparcia udzielanego uczniom $\mathrm{w}$ procesie kształcenia? $\mathrm{W}$ jaki sposób ta propozycja wpisuje się w znane modele diagnozy?

\section{Model niepełnosprawności przyjmowany w ICF a perspektywa rozumienia niepełnosprawności przez osoby pracujące z osobami z niepełnosprawnością}

Niepełnosprawność w Międzynarodowej Klasyfikacji Funkcjonowania, Niepełnosprawności i Zdrowia (International Classification of Functioning, Disability and Heath, ICF) definiowana jest jako wielowymiarowe zjawisko będące skutkiem wzajemnych oddziaływań między jednostką a jej fizycznym i społecznym otoczeniem. Funkcjonowanie i niepełnosprawność to wynik interakcji między warunkami zdrowotnymi (choroby, zaburzenia, urazy) a czynnikami środowiskowymi i osobistymi - związanymi z jednostką [ICF 2009, s. 18-19]. Dwukierunkowe oddziaływania każdego komponentu (stan chorobowy, funkcje i struktury ciała, aktywność, uczestniczenie, czynniki środowiskowe i czynniki osobowe) są odpowiedzią na krytykę powiązań przyjmowanych w Międzynarodowej Klasyfikacji Uszkodzeń, Niepełnosprawności i Upośledzeń (International Classification of Impairments, Disabilities, and Handicaps, ICIDH) [ICIDH 1980]. Linearny związek między uszkodzeniem, ograniczeniami funkcjonalnymi a niepełnosprawnością, przyjmowany w klasyfikacji ICIDH (i innych medycznych klasyfikacjach diagnostycznych), sprowadzał myślenie o niepełnosprawności do prostego faktu: warunkiem koniecznym i wystarczającym do wystąpienia niepełnosprawności jest określone uszkodzenie na poziomie biologicznym. Pewnemu rodzajowi uszkodzenia u osoby można więc przyporządkować ograniczenia funkcjonalne, a tym samym i to,

2 Klasyfikacja ICF-CY (International Classification of Functioning, Disability and Health - Children and Youth) [ICF-CY 2007] jest przeznaczona do badania dzieci i młodzieży w wieku od 0 do 17 lat. Opracowanie klasyfikacji ICF-CY wynikało z potrzeby opisywania funkcjonowania dzieci i młodzieży. Podobnie jak w ICF opisuje osobę z uwzględnieniem podstawowych komponentów. 
jak niepełnosprawność danej jednostki wyraża się (ujawnia) w otoczeniu społecznym (upośledzenie) [Wiliński 2010, s. 41-47]. ICIDH bazowała na modelu medycznym, którego sednem jest przyporządkowanie przyczynom niepełnosprawności, działającym na jednostkę, skutków, które ją dotykają bezpośrednio. Takie ujmowanie niepełnosprawności pozwalało na "obiektywizację zarówno procesu diagnostycznego, jak i form oddziaływania na zjawisko niepełnosprawności, odwołując się do normy biologicznej, wyznaczonej przez teoretycznie skonstruowany ideał kompletnego i prawidłowo funkcjonującego ciała" [Wiliński 2010, s. 34]. Zakładane w ICIDH bezpośrednie i jednokierunkowe przełożenie uszkodzenia na niepełnosprawność i upośledzenie nie tylko nie uwzględniało dynamiki zmian oraz możliwości oddziaływania sposobu funkcjonowania na ogólną kondycję zdrowotną, ale również stwarzało podłoże do naznaczania osób doświadczających obniżenia kondycji zdrowotnej [por. Byra, Boczkowska, Duda 2016].

Złożoność sieci sprzężeń zwrotnych między samymi czynnikami i przebiegiem procesów utraty i odzyskania sprawności od wielu lat jest wyraźnie uobecniona $\mathrm{w}$ polskim piśmiennictwie. S. Kowalik [2007] ilustruje te zależności w odwołaniu do kategorii problemów, które wiążą się z niepełnosprawnością i w których przejawia się dysfunkcjonalność osób niepełnosprawnych. Problem pierwszy odnosi się do zależności między wymaganiami sytuacji i ograniczonymi przez uszkodzenie organizmu możliwościami sprostania tym oczekiwaniom. Problem drugi odnosi się do zależności między aktywnością osoby niepełnosprawnej i konkretnymi sytuacjami życiowymi, w jakich jednostka może się znaleźć. Problemy związane z tą relacją polegają na ograniczaniu sytuacji, w których jednostka podejmuje aktywność oraz na ponoszeniu nadmiernego wysiłku w dążeniu do sprostania wymaganiom sytuacji. Problem trzeci odnosi się do zależności między cechami biologicznymi, osobowościowymi jednostki a doświadczanymi przez człowieka stanami świadomości, chodzi o to, czy właściwości te są w stanie uchronić osobę niepełnosprawną przed nadmiernym stresem oraz $\mathrm{w}$ jakim stopniu negatywne przeżycia zostaną utrwalone w doświadczeniu jednostki, doprowadzając do trwałej modyfikacji osobowości. Problem czwarty odnosi się do wzajemnych oddziaływań między dwiema rodzajami dysfunkcjonalności: behawioralną i świadomościową. Niepowodzenia związane z podjętym działaniem mogą powodować nieprzyjemne przeżycia i odwrotnie, negatywne przeżycia mogą obniżać poziom sprawności behawioralnej. Autor wskazuje na brak prostego związku między zaburzeniem a problemami, jakich doświadcza osoba z niepełnosprawnością. Dopiero w konkretnym badaniu diagnostycznym można jednoznacznie stwierdzić, czy dana osoba posiada określone problemy i jakie jest ich nasilenie. Druga część diagnozy polega zaś na odszukaniu źródeł zaistniałych problemów oraz poznaniu zasobów, które można wykorzystać w skutecznym ich przezwyciężaniu [por. Kowalik 2005]. 
Modele funkcjonalne (a więc również interakcyjny model przyjmowany w ICF), jak podkreśla (w nawiązaniu do standardów kształcenia dla poszczególnych kierunków studiów i poziomów kształcenia) M. Wiliński [2010, s. 50] „wydają się najbliższe perspektywie osobistej ludzi wspomagających osoby niepełnosprawne, czyli ich bliskich i przedstawicieli zawodów zaangażowanych w poradnictwo (psychologów, pedagogów, doradców zawodowych, terapeutów), oraz w działanie na rzecz osób $\mathrm{z}$ niepełnosprawnością $\mathrm{w}$ sektorze społecznym (asystentów pracy, pracowników socjalnych) i pozarządowym. Przedstawiciele wymienianych tu zawodów są profesjonalnie przygotowywani do wielowymiarowego rozumienia sytuacji osób niepełnosprawnych i ujmowania jej w kategoriach środowiskowych, osobowych i interakcji tychże". Można wiec przyjąć, że przekonania tych osób powinny być różne od tzw. wyobrażeń „naiwnych", które łączy on z perspektywą osobistą osób niedotkniętych zjawiskiem i niezaangażowanych wobec zjawiska niepełnosprawności.

Termin „naiwne” w zwrocie „naiwne wyobrażenia niepełnosprawności”, jak wyjaśnia M. Wiliński, należy rozumieć, jako „takie wyobrażenia, które nie mają związków z koncepcjami teoretycznymi i jako takie mogą być uznawane za prawdę wyłącznie w potocznym dyskursie społecznym" [Wiliński 2010, s. 24]. Autor wskazuje jednocześnie, że medyczny model niepełnosprawności bliski jest wyobrażeniom "naiwnym”. Te dwie konceptualizacje niepełnosprawności „odwołują się do normy zdrowego, prawidłowo funkcjonującego ciała (choć norma ta jest inaczej konstruowana: teoretycznie lub statystycznie, a w przypadku naiwnego wyobrażenia niepełnosprawności obejmują jeszcze komponent atrakcyjności ciała) oraz umiejscawiają zjawisko niepełnosprawności w jednostce. Odróżniają je od siebie: inne rozumienie procesu utraty sprawności, dokonywana atrybucja odpowiedzialności oraz stosowane formy i środki pomocy" [Wiliński 2010, s. 35]. Autor zaznacza, że niemożność określenia wyraźnego czynnika, któremu można przypisać powód powstania niepełnosprawności, sprawia, że zobrazowanie procesu utraty sprawności w modelu medycznym nie zawsze jest pełne. „W konsekwencji przypadkom utraty sprawności, takim jak na przykład rzadka choroba genetyczna (i trudno wykrywalna, o charakterze autosomalnym i recesywnym), urazom czy uszkodzeniom mechanicznym niemal zawsze przypisuje się charakter nieszczęśliwego wypadku lub zbiegu okoliczności, co jest charakterystyczne dla rozumienia relacji utraty sprawności w naiwnym wyobrażeniu niepełnosprawności. Jest tu widoczna wyraźna relacja między medycznym a naiwnym modelem niepełnosprawności. Ponadto jest ona wyraźna wobec konsekwencji doświadczeniowych, behawioralnych i społecznych niepełnosprawności" [Wiliński 2010, s. 36]. Zakłada się, że taka osoba musi zmagać się z wieloma problemami, być bierna i wyizolowana (lub przynajmniej zagrożona tymi zjawiskami), wymagać opieki, a jednocześnie stawać przed wieloma trudnymi wyzwaniami, z którymi powinna sobie poradzić. 
Wskazuje się na dominującą rolę modelu medycznego w kształtowaniu percepcji i postaw wobec niepełnosprawności ze względu na łatwość, z jaką system definicyjny i diagnostyczny, stosowany w modelu medycznym, jest odbierany przez opinię publiczną [Wiliński 2010, s. 37]. Badania prowadzone w różnych grupach związanych z pełnieniem pomocy dla osób niepełnosprawnych, dotyczące postaw wobec niepełnosprawności i osób niepełnosprawnych [por. Kossewska 2000; Sudar-Malukiewicz 2001; Zasępa, Czabała, Starzomska 2005; Kirenko 2007; Kaszyński, Cechnicki 2011] pozwalają wnioskować, że osobista perspektywa osób pracujących z osobami z niepełnosprawnością uwzględnia w wyraźnym stopniu ustalenia modelu medycznego. Oznacza to, że wyraźniej wpisuje się w model powiazań przyjmowanych w Międzynarodowej Klasyfikacji Uszkodzeń, Niepełnosprawności i Upośledzeń (ICIDH), niż w model przyjęty w ICF. Biorąc pod uwagę różne grupy zaangażowane w pomoc (pracownicy służby zdrowia, psycholodzy nauczyciele, pracodawcy) można wyszczególnić pewne różnice przekonań dotyczące osób z niepełnosprawnością oraz postrzegania doświadczania niepełnosprawności przez te osoby. Pracodawcy zakładają ograniczenia funkcjonalne osób z niepełnosprawnością i przyjmują, że będą one pracować gorzej niż osoby pełnosprawne, co ogranicza szanse potencjalnego niepełnosprawnego pracownika na otrzymanie zadań ambitnych, trudnych, wymagających motywacji i zmuszających do rozwoju. Osoby zaangażowane w korekcję (i leczenie) niepełnosprawności (przedstawiciele zawodów medycznych) niepełnosprawność postrzegają przez pryzmat ciała; jako właściwość jednostki, na którą można oddziaływać, wykorzystując procedury medyczne. Ta grupa zawodowa nie ma pełnego zrozumienia dla perspektywy osobistej osób niepełnosprawnych. Psycholodzy, pedagodzy, pracownicy socjalni, postrzegają niepełnosprawność przez pryzmat jej konsekwencji. $\mathrm{W}$ ich perspektywie niepełnosprawność jest czynnikiem ryzyka i źródłem trudności doświadczanych przez osoby niepełnosprawne. $Z$ jej powodu konieczne jest wspieranie osób nią dotkniętych tak, by potrafiły sobie poradzić z jej konsekwencjami [por. Wiliński 2010].

Nauczyciele, podobnie jak psycholodzy, przejawiają relatywnie pozytywne postawy wobec niepełnosprawnych, chociaż różniące się w zależności od stopnia niepełnosprawności i rodzaju trudności związanych z tą niepełnosprawnością. Miejsce ich pracy i wykształcenie różnicuje postrzeganie przez nich osób z niepełnosprawnością. Badania Sadowskiej [2005], skoncentrowane na semantycznym aspekcie wypowiedzi nauczycieli o osobach z niepełnosprawnością (nauczyciele proszeni byli o wypisanie skojarzeń z kategorią „osoba niepełnosprawna”) ujawniają, że we wszystkich badanych grupach nauczycieli (nauczyciele szkół specjalnych, integracyjnych i ogólnodostępnych) słowem kluczowym jest rzeczownik "trudności”. Dla nauczycieli osoba niepełnosprawna to osoba: „bezradna”, „zależna od innych osób”, ,zdana całkowicie na pomoc osób trzecich”, „potrzebu- 
je pomocy", „potrzebuje opieki", ale też "potrzebuje tolerancji, miłości, przyjaźni” [Sadowska 2005, s. 102-116]. We wszystkich badanych grupach widoczne były wyrażenia, które przy głębszej analizie okazują się świadczyć o stereotypowym ujmowaniu tych osób. W nielicznych wypowiedziach podkreślany był brak różnicy miedzy osobami niepełnosprawnymi i pełnosprawnymi. Charakterystyczne jest, że tego typu wypowiedzi pojawiły się tylko u nauczycieli szkół specjalnych i integracyjnych. W wypowiedzi nauczyciela szkoły integracyjnej skojarzenie przybrało formę swoistej definicji: »jest to osoba (było to jedyne określenie, nie pojawiły się żadne inne skojarzenia). W wypowiedziach nauczycieli szkół specjalnych podobieństwo osób niepełnosprawnych i sprawnych podkreślają zaimki »każdy«i »wszyscy«. Co ciekawe, są one budowane na zasadzie »nie ma osób sprawnych - wszyscy jesteśmy niepełnosprawni«, różnice jakości wyrażane są poprzez przysłówek »dużo«i przymiotnik »duży«w stopniu wyższym: »wszyscy jesteśmy słabi, niektórzy jedynie mają więcej słabości«, »każdy ma jakąś słabość, jedni w większym, inni w mniejszym stopniu «" [Sadowska 2005, s. 104-105]. Badania Z. Gajdzicy [2013] wskazują, że kluczowe jest przekonanie nauczycieli o biologicznych źródłach trudności osób z niepełnosprawnością i potrzebie specjalistycznych kompetencji $\mathrm{w}$ pracy $\mathrm{z}$ wszystkimi uczniami $\mathrm{z}$ orzeczeniem o potrzebie kształcenia specjalnego. Przeświadczenie to wynika, jak wskazuje Z. Gajdzica, być może, z tradycyjnej izolacji problematyki pedagogiki specjalnej, naukowej hermetyczności tej subdyscypliny pedagogicznej. Innym powodem tego stanu rzeczy jest zapewne akcentowanie (w powszechnym przez wiele lat modelu medycznym niepełnosprawności) znaczenia $w$ procesach wychowania i kształcenia odchyleń biologicznych, traktowanych jako najważniejszy wyznacznik projektowania edukacji specjalnej [Gajdzica 2013, s. 109].

W świetle powyższego nietrudno odnieść się krytycznie do kształcenia kadr dla potrzeb pracy z osobami z niepełnosprawnością, w tym kształcenia nauczycieli dla potrzeb pracy z uczniami ze specjalnymi potrzebami edukacyjnymi (potencjalnie taki uczeń może znaleźć się w każdej klasie). Można podnieść, że w przeciwieństwie do kształcenia na kierunku pedagogika specjalna, w ramach którego studenci nabywają sporej porcji wiadomości o specyficznych potrzebach uczniów niepełnosprawnych, w kształceniu nauczycieli przedmiotu, w związku z ograniczeniami zajęć z zakresu pedagogiki i pedagogiki specjalnej, wiadomości te są pomijane. Wyjściowe stanowiska kandydatów na nauczycieli dotyczące osób $\mathrm{z}$ niepełnosprawnością $\mathrm{w}$ istocie nie mają szansy być rewidowane, gdyż nie gwarantują tego standardy kształcenia nauczycieli. Minimalizowanie kształcenia pedagogicznego w kształceniu nauczycieli stwarza ryzyko zatrudniania kadry o niskich kompetencjach i przygotowaniu do pracy z uczniami ze specjalnymi potrzebami edukacyjnymi [por. Klus-Stańska 2011; Gajdzica 2013; Janiszewska-Nieścioruk, Sadowska 2016]. Zauważyć można, że również pod adresem 
kształcenia pedagogów specjalnych można wyartykułować uwagi krytyczne. Przesłanką jest tu dla przykładu niska frekwencja wypowiedzi nauczycieli szkół specjalnych wskazujących na dostrzeganie podobieństw, a nie różnic miedzy osobami niepełnosprawnymi i pełnosprawnymi. Jednak ta grupa, w odróżnieniu od nauczycieli, tzw. przedmiotowców (fizyków, matematyków, polonistów, biologów itp.) dysponuje dużo większą wiedzą na temat niepełnosprawności i jej istoty, co pozwala nie tylko redukować lęk przed innością dziecka, ale również rozwiązywać skutecznie problemy w procesie edukacyjnym.

Można stwierdzić, że „nauka stawia sobie za zadanie weryfikację naiwnych modeli niepełnosprawności oraz popularyzację wiedzy naukowej, tak by koncepcje naiwne (potoczne) zostały wyparte ze świadomości społecznej przez lepiej udokumentowane teorie lub modele naukowe" [Wiliński 2010, s. 24]. Jednostki kształcenia akademickiego powołane są zaś, by zapoznawać z najnowszymi osiągnięciami nauki. W kontekście przekonań nauczycieli (i innych grup zawodowych) o niepełnosprawności nie można zapominać jednak, że utrwalone schematy myślenia przeorganizowują się powoli. $Z$ dużą ostrożnością należy też podchodzić do twierdzenia, że wiedza naukowa zapewnia wysoki poziom profesjonalizmu. Oprócz wiedzy naukowej wskazuje się na moc regulacyjną w przebiegu praktyki rehabilitacyjnej wiedzy instytucjonalnej i wiedzy potocznej [por. Kowalik 1989]. Cechą wiedzy instytucjonalnej jest jej podzielanie przez członków danej instytucji. Odnieść ją można do przepisów roli własnej i innych ról społecznych w tej instytucji (lub całym zbiorze instytucji, organizacji). S. Kowalik, polemizując ze stanowiskiem J. Brzezińskiego, że wiedza naukowa zapewnia wysoki poziom profesjonalizmu, mówi: „To nie jest chyba tak, jak wyobraża sobie Brzeziński, że zdobyta na studiach wiedza psychologiczna znajduje się $\mathrm{w}$ odrębnym pojemniku w naszych umysłach i możemy tylko sięgać do niego, zajmując się praktyką. Bardziej realistyczna jest taka wersja pracy umysłu (...), w którym miesza się ze sobą wiedza potoczna z wiedzą naukową. Chodzi o to, aby wiedzy naukowej było możliwie dużo i żeby właśnie ona miała odpowiednią moc regulacyjną, gdy przychodzi nam rozwiązywać życiowe problemy naszych klientów" [Kowalik 2011, s. 57]. Podobne uwagi można wyartykułować $\mathrm{w}$ stosunku do pedagogów i nauczycieli oraz wszystkich tych, którzy zajmują się edukacją i rehabilitacją osób z niepełnosprawnością.

\section{Diagnoza oparta na podstawach teoretycznych i metodologii ICF a przesłanki humanistyczne zapotrzebowania na model interakcyjny}

„Klasyfikacja ICF dostarcza opisu sytuacji dotyczących funkcjonowania człowieka i jego ograniczeń oraz służy jako narzędzie do organizacji tych informacji. Tworzy strukturę porządkującą informacje w sensowny, logicznie powiązany 
i łatwo dostępny sposób" [ICF 2009, s. 7]. Kategorie ICF skupione są w dwóch częściach. Część pierwsza klasyfikacji obejmuje „Funkcjonowanie i Niepełnosprawność", a część druga "Czynniki kontekstowe”. Każda z tych część posiada dwa składniki. Dla części pierwszej to „Funkcje i struktury ciała” oraz „Aktywności i uczestniczenie". Składnik pierwszy dotyczy ciała ludzkiego i zawiera dwie klasyfikacje, jedna obejmuje funkcjonowanie (czynności) układów ciała, a druga struktury (budowę) ciała. Składnik drugi obejmuje pełen zakres dziedzin dotyczących funkcjonowania zarówno z perspektywy pojedynczej osoby, jak i społeczeństwa [por. ICF 2009, s. 7-8]. Z dziedzinami tymi związane są takie kwalifikatory jak zdolność i wykonanie. Zdolność to najwyższy możliwy sposób wykonywania danej czynności możliwy do osiągnięcia w znormalizowanym środowisku. Natomiast wykonanie określa możliwości działań osoby w danym (aktualnym) środowisku. Różnica między zdolnością a wykonaniem obrazuje ograniczenia, jakie niesie ze sobą wykonywanie czynności $\mathrm{w}$ aktualnym środowisku, i stanowi podstawę do działań mających na celu poprawę sytuacji [por. ICF 2009, s. 15]. W części drugiej pierwszym składnikiem jest lista "Czynniki środowiskowe”, zaś drugim "Czynniki osobowe". Czynniki osobowe nie zostały sklasyfikowane w ICF ze względu na związane z nimi duże zróżnicowanie społeczne i kulturowe. Zalicza się do nich: płeć, rasę, wiek, sprawność fizyczną, styl życia, nawyki, sposób radzenia sobie $\mathrm{z}$ trudnościami. W razie potrzeby ocenę ich wpływu na dziedziny funkcjonowania pozostawia się użytkownikowi [por. ICF 2009, s. 16, 19]. Użytkownikom bezwzględnie zaleca się przeszkolenie $\mathrm{w}$ wykorzystaniu klasyfikacji prowadzone przez WHO i sieć ośrodków współpracujących. Znaczące dla wykorzystania tej klasyfikacji są jej cechy strukturalne. Pomimo dostępności tej klasyfikacji czytelnikowi na gruncie polskim, warto zwrócić uwagę na kluczowe kwestie [ICF 2009, s. 21-23]:

- „ICF stosuje system alfanumeryczny, w którym litery b, s, d i e oznaczają Funkcje ciała ludzkiego, Struktury ciała ludzkiego, Aktywności i Uczestniczenie oraz Czynniki środowiskowe. Po literach następuje kod numeryczny, który rozpoczyna się od numeru rozdziału (jedna cyfra), po którym następuje drugi poziom (dwie cyfry) oraz trzeci i czwarty poziom (jedna cyfra na każdy).

- Kategorie ICF są „zagnieżdżone” tak, że szersze kategorie zawierają bardziej szczegółowe podkategorie (...).

- Każda osoba może być opisana przy pomocy kodów na każdym poziomie. Kody mogą być niezależne od siebie lub ze sobą powiązane.

- Kody ICF są kompletne tylko wtedy, gdy występują wraz z kwalifikatorem wskazującym na poziom stanu zdrowia (np. stopień nasilenia problemu zdrowotnego). (...) Użyciu każdego z kodów powinien towarzyszyć co najmniej jeden kwalifikator. Bez kwalifikatorów kody pozbawione są właściwego znaczenia. 
- Pierwszy kwalifikator dla składnika Funkcje i Struktury ciała ludzkiego, kwalifikatory wykonanie i zdolności dla składnika Aktywności i Uczestniczenie oraz pierwszy kwalifikator dla składnika Czynniki środowiskowe służą do opisu stopnia lub rozmiaru problemu dla odpowiedniego składnika klasyfikacji.

- Wszystkie trzy składniki sklasyfikowane w ICF („Funkcje i struktury ciała”, "Aktywności i uczestniczenie", oraz "Czynniki środowiskowe”) określane są ilościowo przy użyciu tej samej ogólnej skali. Problem może oznaczać upośledzenie, ograniczenie, zawężenie, lub barierę w zależności od konstrukcji (...).

- W przypadku czynników środowiskowych pierwszy kwalifikator może służyć zarówno do określania zakresu pozytywnych aspektów środowiska, tj. ułatwień, jak też do określania zakresu efektów negatywnych, tj. barier. (...) Czynniki środowiskowe można kodować (a) w odniesieniu do każdej konstrukcji oddzielnie lub (b) ogólnie, bez odniesienia do określonej konstrukcji. Preferuje się pierwszą możliwość, jako lepiej określającą wpływ danego czynnika (...).

- W ICF stan zdrowia danej osoby i elementów z nim związanych określa się przy pomocy szeregu kodów, które obejmują obie części klasyfikacji. W związku z tym maksymalna liczba kodów dla jednej osoby wynosi 34 na poziomie jednocyfrowym (8 funkcji ciała ludzkiego, 8 struktur ciała, 9 dla wykonania i 9 dla zdolności). Analogicznie, kodów drugiego poziomu jest 362. Przy bardziej szczegółowej klasyfikacji liczba kodów wynosi 1424. W rzeczywistych zastosowaniach ICF zestaw od 3 do 18 kodów może być wystarczający, aby opisać przypadek z dokładnością do drugiego poziomu (trzy cyfry). Bardziej precyzyjny zapis czwartego poziomu jest na ogół wykorzystywany w usługach specjalistycznych (np. wyniki rehabilitacji, geriatria), podczas gdy klasyfikacja drugiego poziomu może być wykorzystywana do oceny badań sondażowych i badań klinicznych".

W ICF ludzie nie są jednostkami klasyfikacji; to znaczy ICF nie klasyfikuje ludzi, ale opisuje sytuację każdej osoby w sieci dziedzin zdrowia lub dziedzin powiązanych ze zdrowiem. Opis powstaje zawsze w kontekście czynników środowiskowych i osobowych [ICF 2009, s. 8]. Użytkownik klasyfikacji może tworzyć odpowiednie dla danego przypadku profile funkcjonowania, niepełnosprawności i zdrowia w różnych dziedzinach. Dzięki korzystaniu z ICF różni specjaliści mogą uzyskać pełniejszy ogląd problemów swoich podopiecznych. Ten aspekt podnoszony jest także przez same osoby niepełnosprawne $-\mathrm{w}$ ich opinii ten system klasyfikacyjny lepiej oddaje istotę wszystkich ich problemów życiowych od klasyfikacji medycznych [por. Wiliński 2010, s. 38].

ICF może być wykorzystywana przez szerokie spektrum rozmaitych użytkowników w różnych celach - znajduje zastosowanie w badaniach nad systemami opieki zdrowotnej, zarówno w ich ocenie, jak i kształtowaniu właściwej polityki w tym zakresie, w działaniach służących zwiększeniu uczestniczenia w życiu 
społecznym przez usuwanie lub zmniejszanie barier społecznych oraz zapewnienie wsparcia społecznego i ułatwień. W oparciu o tak przeprowadzoną diagnozę potrzeb zalecane są standardy pomocy rehabilitacyjnej oferowane osobom $\mathrm{w}$ instytucjach opiekuńczych i edukacyjnych.

Oparcie projektów pomocy na klasyfikacji ICF jest wartościowe, chociaż można podnieść pewne obawy z tym związane. Jak wskazuje Jagodziński [2013, s. 71], tworzeniu koncepcji projektu aktywizacji osób niepełnosprawnych zgodnego $\mathrm{z}$ duchem ICF towarzyszyły niepokoje związane $\mathrm{z}$ jednej strony z bardzo rozbudowaną dokumentacją związaną z pracą z osobami niepełnosprawnymi, którą realizuje się na podstawie ICF, z drugiej zaś obawy, że relacja z osobą niepełnosprawną straci swoją autentyczność (relacja ta ograniczona będzie w pewnym stopniu przez formalnie wyznaczone ramy, oznaczające konieczność prowadzenia wywiadu według określonych wytycznych, gromadzenia informacji oraz programowania działań wraz ze wskazaniem oczekiwanych efektów), co ostatecznie wiązać się może z ryzykiem mniejszej wiarygodności w oczach osoby z niepełnosprawnością i osłabieniem oddziaływań motywacyjnych. Lękano się także tego, że konstruowane opisy ograniczeń i upośledzeń związanych z niepełnosprawnością będą pomijać wiele ważnych wątków i to pomimo hierarchicznej struktury oraz dużego stopnia skomplikowania i szczegółowości kategorii ICF, zaś programowanie aktywizacji obarczone będzie dużym ryzykiem z uwagi na dynamikę oraz zmienność sytuacji osoby niepełnosprawnej, spowodowaną etapowością procesu niepełnosprawności i możliwymi komplikacjami, które mogą mu towarzyszyć. Jagodziński podkreśla, że „argumentami, które zdecydowały ostatecznie o zmianie nastawienia osób, początkowo dystansujących się do idei projektu opartej na ICF, były: zakładana i widoczna w warstwie teoretycznej oraz konkretnych działaniach podmiotowość beneficjentów, a także nie mniej istotna konstrukcja porządkująca pracę z niepełnosprawnymi od etapu nawiązania kontaktu do etapu testowania zdobytych umiejętności w naturalnym środowisku osoby i końcowej ewaluacji" [Jagodziński 2013, s. 72].

W podobnym duchu wypowiadają się też teoretycy optujący za humanistyczną wizją uprawiania zawodu pomocowego. S. Kowalik argumentuje, że praktyka rehabilitacyjna nie może być rutynowym działaniem, w którym drugi człowiek jest obiektem diagnozy, psychoterapii, konsultacji, wspomagania jego rozwoju. Nie można zajmować wobec ludzi pozycji znikąd (czyli obiektywnej), czego wymaga klasyczne poznanie naukowe (również to z zastosowaniem IFC) chodzi o ustosunkowanie się do ich problemów, przyjmując własny punkt widzenia i dzieląc się nim z osobami, które nam zaufały na tyle, że wymagają od nas odrzucenia rutyny zawodowej [por. Kowalik 2011, s. 56]. W myśl tego stanowiska, ICF (jako swoistego rodzaju diagnoza) oraz opis profilu funkcjonowania może być wartościowym rozwiązaniem dla przykładu w eliminowaniu sytuacji proble- 
mowych osób z niepełnosprawnościami. Może służyć eliminacji rozpoznanych barier lub zastosowania ułatwień $w$ środowisku. Jednak nie może nas to zwalniać $\mathrm{z}$ humanistycznej postawy oddawania głosu samej osobie niepełnosprawnej i reagowania na subiektywnie odczuwane problemy [Kowalik 2007, s. 104-107]. Autor rehabilitację postrzega bowiem szeroko jako proces pomocy w likwidowaniu predyspozycji do powstawania sytuacji problemowej, pomocy w likwidowaniu obiektywnych problemów oraz pomocy w likwidowaniu subiektywnie odczuwanych problemów życiowych [Kowalik 1996].

Ocena wagi problemów może się okazać zróżnicowana, a tym samym odmiennie "definiowana" - z perspektywy osobistej osoby z niepełnosprawnością, $\mathrm{z}$ perspektywy środowisk, $\mathrm{w}$ których funkcjonuje (w procesie protodiagnozy), ale też z perspektywy diagnostów zaangażowanych $\mathrm{w}$ interakcję. Te różne perspektywy uwzględnia interakcyjne podejście do diagnozy. W myśl modelu diagnozy interakcyjnej definicja problemu uzgadniana jest wspólnie drogą negocjacji (to sprzyja zaangażowaniu osoby $\mathrm{w}$ realizację zaleceń wynikających z postępowania diagnostycznego). Ważną cechą $w$ tym modelu jest partnerski stosunek między osobą diagnozującą i osobą z niepełnosprawnością. Model ten uwzględnia również fakt, że działalność diagnostyczna nie przebiega w próżni społecznej - osoba z niepełnosprawnością ma swoje „zaplecze społeczne”. Stosunek aktywny do diagnozy ma też jej otoczenie, w którym przebiega proces rozpoznania społecznego (protodiagnoza). Diagnoza interakcyjna to rozwinięcie diagnozy różnicowej i funkcjonalnej. $\mathrm{W}$ modelu tym zapewniona jest relacja symetryczna $\mathrm{w}$ definiowaniu problemu. Dodać można, że w diagnozie interakcyjnej, w odróżnieniu od wcześniejszych modeli (diagnozy różnicowej i funkcjonalnej) coraz mniej jednoznaczne są czynności diagnostyczne, odmienna jest funkcja diagnozy dla terapii, coraz bardziej złożone są cele diagnostyczne. $\mathrm{W}$ diagnozie interakcyjnej diagnosta musi posiadać gruntowną wiedzę, by zinterpretować całokształt zebranych informacji w kontekście określonej teorii tak, aby wyjaśnić problemy badanego, musi umieć prowadzić negocjacje, by osiągnąć uzgodnienie definicji problemu [por. Kowalik 2005].

\section{Podsumowanie}

Praktyczne spełnienie prowadzenia diagnozy interakcyjnej może być wyraźnie osłabione odgórną wykładnią diagnozy w duchu funkcjonalnym. Wskazanie przez władze oparcia diagnozy o ICF rodzi duże oczekiwania wobec praktyków oczekiwania $\mathrm{w}$ zakresie rozumienia podstaw teoretycznych ICF i oczekiwania $\mathrm{w}$ zakresie wiedzy o modelu tej diagnozy oraz znaczeniu tego modelu dla organizacji procesu rehabilitacji (jego możliwościach i ograniczeniach). 
Zderzenie tych oczekiwań z rzeczywistością praktyczną nie napawa optymizmem - osobista perspektywa niepełnosprawności osób zaangażowanych w pomoc oraz podejście do diagnozy najczęściej wyraźnie odbiega od wykładni teoretycznej, na jakiej opiera się model interakcyjny. Nie zabezpiecza także nieraz realizacji diagnozy w duchu funkcjonalnym, jaką pozwala realizować klasyfikacja ICF. W kontekście zapowiedzi MEN w sposób szczególny niepokoją wyniki badań dotyczące procesu diagnozy prowadzonej przez nauczycieli, gdyż to oni podejmują coraz liczniej pracę z uczniami ze specjalnymi potrzebami. W ich świetle diagnoza nauczycielska jest bardzo daleka od profesjonalnej. Nie odbiega w swojej strukturze, jakości i merytoryce od diagnoz dokonywanych intuicyjnie i przez pryzmat silnych emocji przez samych rodziców uczniów ze specjalnymi potrzebami [Konieczna, Konieczna 2010; Jachimczak 2012]. Nauczyciele, przy braku kompetencji do diagnozy, często mają przekonanie, że diagnoza nauczycielska jest tylko utrudnieniem i niczemu nie służy. „Działania diagnostyczne są więc przez nich redukowane, szablonowo powielane, spełniają wyłącznie wymogi formalne, są wykorzystywane nieracjonalnie, według "gotowców«" [za: Tersa 2014, s. 99]. Ważną funkcję $\mathrm{w}$ postępowaniu nauczycieli w obszarze diagnozy pełni wiedza instytucjonalna. Wiedza ta jest przyjmowana w sposób powszechny przez członków, nie wymaga uzasadniania, nie podlega przetwarzaniu przez użytkowników. Tak rozumiana wiedza narzuca pewną sztywność postępowania i wymusza dopasowanie się do panujących reguł, aczkolwiek nie oznacza konieczności identyfikowania się z nią członków instytucji. Badania K. Tersy w ramach przewodu doktorskiego pozwalają wnosić, że kulturę szkoły tworzą niskie oczekiwania wobec spełniania obowiązków diagnostycznych i przyzwolenie na wskazaną wcześniej ignorancję [por. Tersa 2014, s. 99].

Kwestię niskiej wiedzy nauczycieli oraz niewielkiej mocy regulacyjnej wiedzy naukowej na przebieg praktyki można odnieść nie tylko do tego, że minimalizowane jest pedagogiczne kształcenie nauczycieli, ale także do tego, że kształt studiów ukierunkowany jest coraz wyraźniej na zapotrzebowanie "turysty". Studenci oczekują, jak to ujmują, "wiedzy praktycznej”, zaś przedmioty teoretyczne postrzegają jako „nieprzydatne” [Sadowska 2014]. Nie bez znaczenia jest też zjawisko pozorowania studiowania, które można odnieść do niewielkiej ilości czasu przeznaczanego przez studentów na przygotowywanie się do zajęć i wyraźnie niskiego progu liczby czytanych przez nich tekstów naukowych [por. Mikut 2014]. Deklaracje studentów o czytaniu dość dobrze wpisują się w wyniki ogólnych badań czytelnictwa z ostatnich lat, z których wynika, że ani jednej książki w ciągu 2015 roku nie przeczytało aż 33\% uczniów i studentów. Tekstu dłuższego niż 3 strony maszynopisu lub 3 ekrany monitora w ostatnim miesiącu przed badaniami nie przeczytało aż 27\% uczniów i studentów [Michalak, Koryś, Kopeć 2016]. 
Badania z 2016 roku tę sytuację potwierdzają [por. Koryś, Kopeć, Zasacka, Chymkowski 2017].

Złożoność działań w konwencji traktowania rehabilitacji jako pomocy w rozwiązywaniu problemów musi uwzględniać szeroki horyzont wiedzy i opierać się na odpowiedzialnej postawie uwzględniania różnych punktów widzenia na sytuację osób z niepełnosprawnością. Współczesny paradygmat pracy z osobą niepełnosprawną łączy obiektywny aspekt obniżenia poziomu funkcji z procesem podmiotowego przepracowania tego stanu oraz odniesienia aktualnej kondycji jednostki i jej potencjalnych możliwości do otoczenia, w jakim egzystuje. Rehabilitacja to proces pomocy w likwidowaniu predyspozycji do powstawania sytuacji problemowej, pomocy w likwidowaniu obiektywnych problemów oraz pomocy w likwidowaniu subiektywnie odczuwanych problemów życiowych. Powtórzyć można jeszcze raz przywołane wcześniej słowa: gdy przychodzi nam rozwiązywać życiowe problemy osób, z którymi pracujemy, ważne, by wiedzy naukowej było możliwie dużo i żeby właśnie ona miała odpowiednią moc regulacyjną.

\section{Bibliografia}

Byra S., Boczkowska M., Duda M. (2016), Wspótczesne konteksty znaczeniowe terminu "niepetnosprawność" - implikacje Międzynarodowej Klasyfikacji Funkcjonowania, Niepetnosprawności i Zdrowia (ICF), „Człowiek - Niepełnosprawność - Społeczeństwo”, nr 4, s. 15-32.

Gajdzica Z. (2013), Źródła wiedzy polskich i czeskich nauczycieli na temat przemian kształcenia uczniów niepetnosprawnych - doniesienie z badań, "Studia Edukacyjne”, nr 24, s. 103-114.

ICF przekład w języku polskim: Międzynarodowa Klasyfikacja Funkcjonowania, Niepetnosprawności i Zdrowia (2009), Światowa Organizacja Zdrowia, Centrum Systemów Informacyjnych Ochrony Zdrowia.

ICF-CY: International Classification of Functioning, Disability and Health for Children and Youth (2007), World Health Organization, Geneva.

ICIDH: International Classification of Impairments, Disabilities, and Handicaps: a manual of classification relating to the consequences of disease (1980), World Health Organization, Geneva.

Jachimczak B. (2012), Przygotowanie nauczycieli wychowania przedszkolnego do realizacji wybranych zadań z zakresu pomocy psychologiczno-pedagogicznej, "Studia Edukacyjne", nr 21, s. $163-175$.

Jagodziński R. (2013), Zastosowanie ICF jako narzędzia diagnozy, planowania i ewaluacji w programie aktywizacji społecznej i zawodowej osób niepełnosprawnych ruchowo, „Niepełnosprawność - zagadnienia, problemy, rozwiązania" nr II; s. 67-104.

Janiszewska-Nieścioruk Z., Sadowska S. (2016), Problemy związane z probolońskim kształceniem pedagogów i nauczycieli w Polsce, „Niepełnosprawność. Dyskursy Pedagogiki Specjalnej" nr 23, s. 13-31.

Kaszyński H., Cechnicki A. (2011), Polscy pracodawcy wobec zatrudniania osób chorujących psychicznie, „Psychiatria Polska” t. XLV, nr 1, s. 45-60.

Kirenko J. (2007), Indywidualna i społeczna percepcja niepetnosprawności, Wydawnictwo Uniwersytetu Marii Curie-Skłodowskiej, Lublin. 
Klus-Stańska D. (2011), Kształcenie nauczycieli w Polsce w oderwaniu od wspótczesnej pedagogiki, „Rocznik Pedagogiczny”, t. 34, s. 43-50.

Konieczna A., Konieczna I. (2010), Ocena i wyjaśnienie niepowodzeń edukacyjnych uczniów przez nauczycieli i rodziców [w:] Diagnozowanie potrzeb edukacyjnych dziecka, red. A. Konieczna, Wydawnictwo APS, Warszawa, s. 115-128.

Koryś I., Kopeć J., Zasacka Z., Chymkowski R. (2017), Stan czytelnictwa w Polsce w 2016 roku, Biblioteka Narodowa, Warszawa [dostęp: 15.06.2017].

Kossewska J. (2000), Uwarunkowania postaw. Nauczyciele i inne grupy zawodowe wobec integracji szkolnej dzieci niepetnosprawnych, Wydawnictwo Naukowe Akademii Pedagogicznej, Kraków.

Kowalik S. (1989), Upośledzenie umysłowe. Teoria i praktyka rehabilitacji, Państwowe Wydawnictwo Naukowe, Warszawa-Poznań.

Kowalik S. (1996), Psychospołeczne podstawy rehabilitacji osób niepełnosprawnych, Wydawnictwo „Interart”, Warszawa.

Kowalik S. (2005), Modele diagnozy psychologicznej [w:] Psychologia kliniczna, t. 1, red. H. Sęk, Wydawnictwo Naukowe PWN, Warszawa, s. 181-192.

Kowalik S. (2007), Psychologia rehabilitacji, Wydawnictwa Akademickie i Profesjonalne, Warszawa.

Kowalik S. (2011), O reputacji psychologii i psychologów, „Roczniki Psychologiczne”, nr 2, s. 53-59.

Michalak D., Koryś I., Kopeć J. (2016), Stan czytelnictwa w Polsce w 2015 roku: wstępne wyniki, Biblioteka Narodowa, Warszawa, http://nck.pl/media/attachments/317769/Stan\%20 czytelnictwa\%20w\%20Polsce\%20w\%202015\%20r._BN_0416.pdf [dostęp: 2.09.2016].

Mikut M. (2014), Zaangażowanie w studiowanie czy pozorowanie? „Pedagogika Szkoły Wyższej”, nr 1, s. 105-121.

Reforma edukacji a uczeń ze specjalnymi potrzebami edukacyjnymi, Departament Informacji i Promocji Ministerstwo Edukacji Narodowej, komunikat 24 lutego 2017, https://men. gov.pl/ministerstwo/informacje/reforma-edukacji-a-uczen-ze-specjalnymi-potrzebamiedukacyjnymi.html [dostęp:25.02.2017r.].

Sadowska S. (2005), Ku edukacji zorientowanej na zmianę społecznego obrazu osób niepetnospraznych, Wydawnictwo Edukacyjne AKAPIT, Toruń.

Sadowska S. (2014), "Trafiliśmy do nieznanego miasta, a ktoś poradzit, żebyśmy zapuścili się w zarośla miedzy dwiema nowymi kamieniczkami" - podróż po mieście naukowym pedagogiki specjalnej, „Człowiek - Niepełnosprawność - Społeczeństwo”, nr 3, s. 21-34.

Sudar-Malukiewicz J. (2001), Nauczyciele szkót specjalnych i masowych wobec procesu integracji społecznej osób upośledzonych umystowo [w:] Paradygmaty i przeobrażenia edukacji specjalnej świetle dorobku profesora Aleksandra Hulka, red. G. Dryżałowska, Wydawnictwo Akademickie "Żak", Warszawa.

Tersa K. (2014), Kompetencje diagnostyczne nauczycieli: oczekiwania i wyzwania , „Niepełnosprawność. Dyskursy Pedagogiki Specjalnej", nr 16, s. 90-105.

Wiliński M. (2010), Modele niepetnosprawności: indywidualny - funkcjonalny - spoteczny [w:] Diagnoza potrzeb i modele pomocy dla osób z ograniczeniami sprawności, red. A. I. Brzezińska, R. Kaczan, K. Smoczyńska, Wydawnictwo Naukowe Scholar, Warszawa, s. 15-59.

Zasępa E., Czabała C., Starzomska M. (2005), Postawy wobec niepetnosprawności i osób niepetnosprawnych, "Człowiek - Niepełnosprawność - Społeczeństwo”, nr 1, s. 23-36. 